\title{
DAIMLER PROCESS AUDIT PREPARATION, EXECUTION AND EVALUATION IN FAURECIA KOSICE
}

\author{
LUBOMIR LENGYEL
}

\section{INTRODUCTION}

Faurecia Slovakia, plant Kosice is a part of the company Faurecia which is leading supplier of automotive industry worldwide. Plant Kosice is a part of the Faurecia's business group Interior Systems and is specializing in the leather processing. Kosice plant is delivering Instrument Panels, Door Panels and various interior part of the cars covered with natural or artificial leather to 11 customers in Germany, France, Great Britain, South Africa, Poland and Slovakia. OEM's supplied by Kosice are PSA, Land Rover, Ford, and Volvo.

In order to enlarge portfolio of the supplied OEM's and also enter into the premium luxury segment of the cars it was decided on the group level to enter into the acquisition process of the current Mercedes-Benz S-class car.

S-class doorpanels and central console were in that time supplied by Faurecia's competitor in field of interior systems. An offer was placed to Daimler with intention to insource the production activities from the competitor. This offer was principally accepted by Daimler, so further negotiations with competitor, so as Daimler customer could follow-up.

As the result it was agreed to insource firstly central console of S-Class and based on the result of this insourcing further actions will be decided by Daimler. First and only condition placed by Daimler was to pass the Daimler Process Audit (DPA) on the S-class central console product coded internally by Daimler as W221 program.

\section{METHODOLOGY}

\subsection{Used methodologies}

This paper is describing the process of preparation to successful passing DPA. From process point of view VDA 6.3 standard has been the base accompanied with Daimler additions, driven by internal Faurecia Audit standard. Continual improvement process based on Deming's cycle has been applied. 


\subsection{DPA Preparation process}

The planning and preparation for an internal quality management systems audit, for example as specified by ISO 9001:2008, "Quality Management Systems requirements" is possibly the most important aspect in ensuring the effectiveness of that audit (Nichols, 2010).

Beside production transfer preparation and realization a separate workgroup was established in Faurecia plant Kosice with only target to prepare the plant for successful passing of DPA. Workgroup consist of the Kosice plan management team (plant manager, quality manager, logistic manager, production manager), Faurecia plant Boblingen and Scheuerfeld management team (plant and quality managers) which were in that time already supplying W221 products to Daimler and also development team from Faurecia development center in Hagenbach (program manager, commodity manager, program quality managers). This team was led by Kosice quality manager as the main contact for Daimler in case of W221 insourcing to Kosice. Team members were all specialist in various processes and thus building of such cross sectional team should lead to success based on the knowledge base present.

Regular meeting dates were established (lead time from insourcing to DPA was only 3 months, thus meetings took place on weekly basis).

As first step it was decided to perform a special training for DPA and Daimler customer special requirements for all team members. This training was provided by the representatives of the Boblingen and Scheuerfeld plants.

DPA is based on the VDA 6.3 standard, which is common for German automakers. So far standard for process audits applied in Faurecia was QS 9000 standard for all non-german OEM's and FIEV standard for PSA.

Various differences were identified and discussed their application.

Standard VDA 6.3 process audit consists of 7 chapters

1 - Product development planning

2 - Realizing product development

3 - Process development planning

4 - Realizing process development

5 - Suppliers / Input material

6 - Production process

6.1 - Personnel / qualification

6.2 - Production material-equipment

6.3 - Transport / Parts Handling / Storage / Packaging

6.4 - Fault Analysis / Correction / Continual improvement

7 - Customer service-customer satisfaction-service 

chapters

DPA standard is based on VDA6.3 with additional points/questions in M1 - Product development planning

M1.6 - Will a fallback solution for product malfunctions or identified risks be elaborated during development?

M1.7 - Is the identification of special characteristics ensured on the basis of requirement and are the requirement regarding the traceability of the products and characteristics safeguarded?

M1.8 Are external development partners integrated and are they controlled?

M3 - Process development planning

M3.7 - Have the suppliers for procedures, tools, machines, services etc. been integrated in process development?

M4 - Implementing process development

M4.7 - Do the process related obligations of the suppliers for procedures, tools, machines, and services that must be fulfilled at the relevant times comply with the process development plan?

M5 - Suppliers / Input Material

M5.10 - Is a process for monitoring the procurement market in place and are measures derived from market observations and requirements forecasts?

M5.11 - Is the availability of input material (components) ensured in the event of increased demand when series production is launched and after it is complete?

M5.12 - Are the required suppliers integrated in the new product project and are they familiar with the customer requirements?

M5.13 - Have the risks in the supply chain been determined and counteracted by means of suitable measures?

M5.14 - Are process audits in accordance with VDA6.3 or similar method planned and performed during the development phase for suppliers commissioned for new product projects?

M6.2 - Production Material / Equipment

M6.2.8 - Are the machines and equipment serviced and maintained on a preventive basis (e.g. by means of routines) as well as on an anticipatory basis (by means of maintenance schedules) and, in turn, $s$ the availability of the machines improved?

M6.2.9 - Do the recordings made during the processes ensure the required level of traceability? 
M6.2.10 - Are legal requirements regarding the handling of waste and hazardous substances fulfilled? (environment)

M6.2.11 - Are the requirements associated with the construction and operations of a plant fulfilled? (environment)

M6.4 - Non conformity analysis / corrective actions / continuous improvement M6.4.7 - Has a suitable procedure for re-qualifying products on a regular basis been defined and implemented?

M6.4.8 - How are changes to the product or process handled, monitored and documented during series production?

In order to collate the VDA and Daimler standard into one common questionnaire, checklist was prepared cross linking both standards with clear description of the requirements (Figure 1).

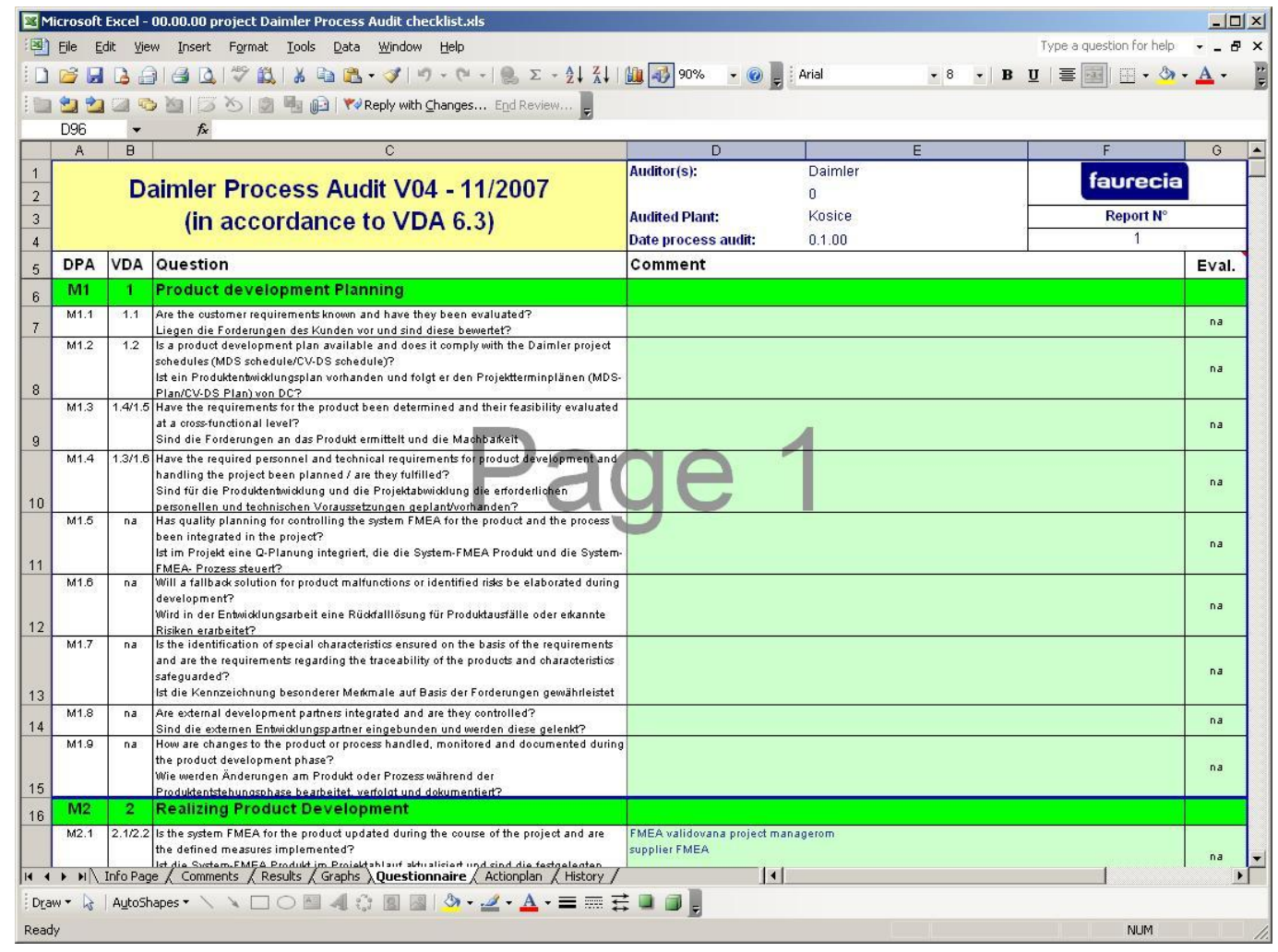

Figure 1 - Process audit questionnaire (Schmidt, 2007)

Main effort was put in preparation of the chapter suppliers - input material. Reason for this was the previous experience with Daimler and their philosophy 
of quality. Daimler understanding of the automotive production process is different than other automakers due to the quality expected from Daimler cars and Daimler customer expectations from cars. Thus Daimler philosophy is "how you are able to treat your suppliers, that way at least you will treat your production process and customers".

Using the ISO 9000 'normative reference' or vocabulary document, we know that a process is defined as "activities which transform inputs into outputs" and, if we apply this definition to a typical assignment, e.g. a manufacturing process, it might be a reasonable expectation that an auditor should study and understand the defined process inputs, activities and outputs, as described by the organization's quality system documentation (Nichols 2010).

Due to this approach part 3 of VDA is the major one and most of the DPA time is spent there. Additional points of Daimler interest in this point are described in section M5, point M5.10-M5.14.

From this can be seen major Daimler interest into the ability to continuously supply selected products preventing major disturbances of the supply flow by various reasons (quality, delivery, process issues).

In production process part of DPA another approach of Daimler could be seen. According Daimler every automotive supplier should not only be able to prevent delivering NOK parts to the customer, but should be able to produce only OK parts. Other words said, major task for Daimler are not the control and evaluation processes, but the process control and ability to develop and maintain stabile and effective processes.

This approach is similar to the one appliled in Faurecia (layered process audit LPA). LPA is an ongoing system of process checks that verify proper methods, settings, operator craftsmanship, error proofing devices and other inputs are in place to ensure a defect free product (Risner 2010).

Keeping in mind those major principles of Daimler a first internal DPA was performed in Kosice. All parts and processes were audited by Audit team built of Quality Managers of Boblingen, Scheuerfeld and Kosice. Result of this first preaudit was $68 \%$ status red, not passed. Daimler's evaluation of the process audit is based on percentage of correctly covered questions from DPA and color codex based on the percentage result achieved. Less than $60 \%$ status red, ranking $\mathrm{C}-$ not passed, $60 \%-80 \%$ status yellow, ranking B - partially passed, $80 \%-90 \%$ status yellow, ranking $\mathrm{AB}$ - major compliance, more than $90 \%$ status green, ranking $\mathrm{A}$ - passed.

Based on this result an action plan based on outcomes of this first pre-audit was established. Countermeasures, improvement actions, responsible and deadlines were defined and agreed (Figure 2). 


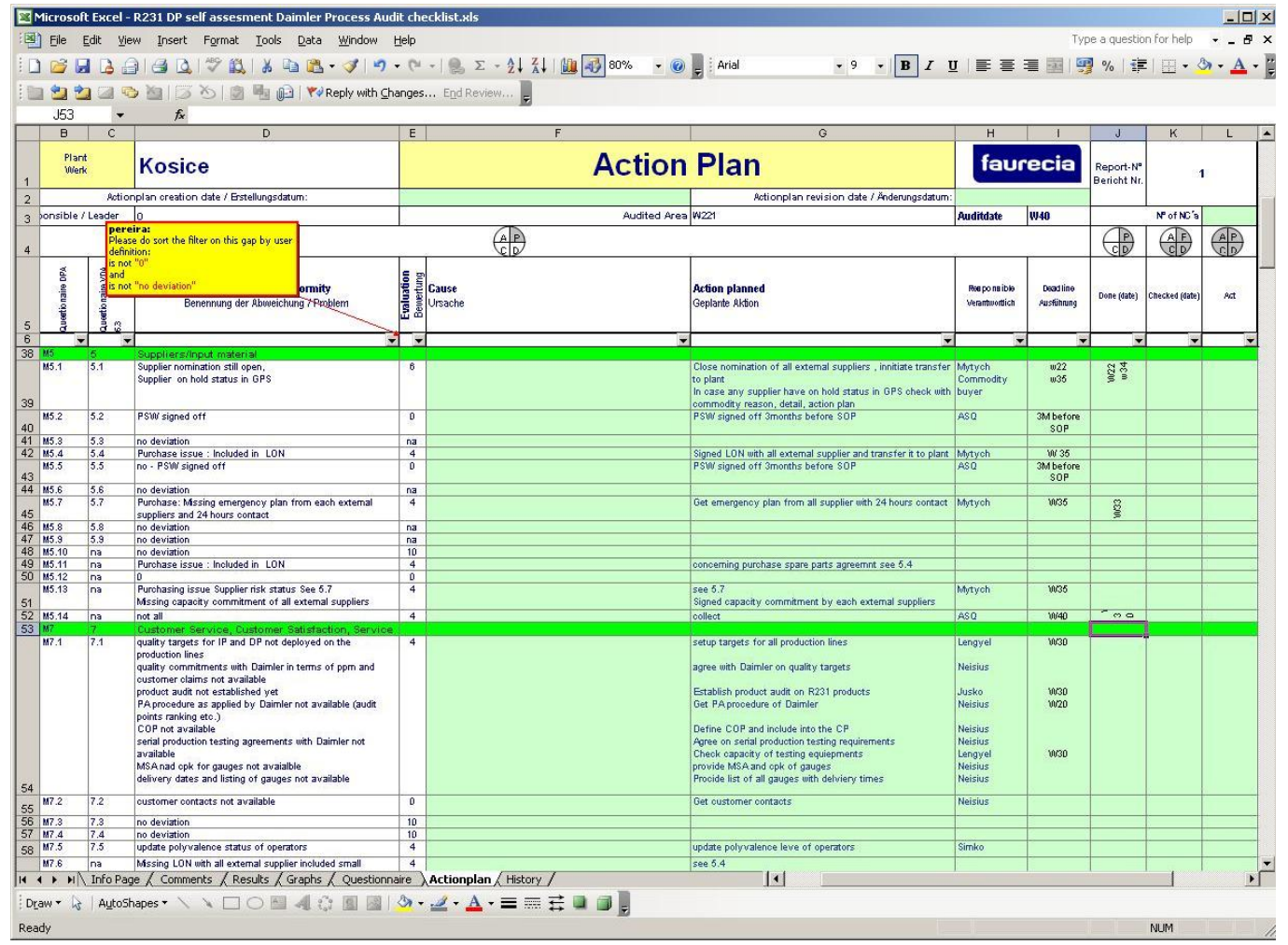

Figure 2 - Action plan from pre-audit

Further it was agreed to perform series of additional re-audits on monthly basis in order to track the follow-up and deal with additional points popped out in the meantime.

To the re-audit which took place exactly 1 month after first audit was invited group audit specialist in order to support the DPA team with additional points of view. Result of this re-audit was 79\% status yellow partially passed. Feedback from group specialist was positive in terms of plant preparation regarding expectations of Daimler.

Last audit took place 1 month before official Daimler DPA. Result was $91 \%$ status green passed. During the audit it was agreed to closely watch the last outstanding issues and the way of DPA support. 


\subsection{DPA realization process}

As a preparation for the Daimler visit and audit a special committee was held with intention to plan in detail whole visit in terms of transport, arrival, refreshments, presentation of plant, audit planning, debriefing etc.

As the most important point was identified the need of planning the exact way of plant tour in order to show to customer all the processes to be audited in process flow way. This plant tour should show the customer the highlights of the processes, so as to present the plant in best possible picture.

Second important point was the exact planning of the audit schedule with time windows needed for evaluation of each phase and with presence of all necessary personnel in order to decrease the possible delays.

Trial plant tour was organized one day before customer arrival identifying last outstanding issues and clarifying all open points.

During the DPA performed by representatives of quality, engineering and development of Daimler none of the serious issues was identified. Daimler representatives have deeply reviewed all process steps with special attention to the incoming inspection of parts and measurement of the dimensional parameters of parts as delivered to customer.

21 points of improvement summarized in action plan allowed Kosice to improve the processes and be more coherent with expectations of the customer in premium segment of the automotive industry, so as be more competitive in future acquisitions.

Final result of the DPA was $96,6 \%$, status green passed.

This result was a benchmark level all over the Faurecia group as such result was never achieved by any Faurecia supplying Daimler and according information given during the debriefing session, it was the best result achieved worldwide in the interior systems suppliers of Daimler.

\section{CONCLUSION}

Overall result of the DPA performed on W221 project in Kosice, was an acknowledgement of the preparation process established in the past, thoroughly monitored and evaluated on regular basis and closely followed by whole management team with deep involvement of all Faurecia Kosice plant team members.

By application of such process thoroughly all over projects established in Faurecia Kosice, so as sharing this lessons learned with other Faurecia plants enables Faurecia group to be more competitive in automotive world and be able to offer to customers stat-of-the-art processes with high self-improvement potential improving efficiency of production processes run in series life of various projects 


\section{REFERENCES}

Faurecia Interior Systems (2007), Daimler process audit checklist version 4.0 $11 / 2007$.

Nichols, A. W. (2010), "Internal Audit Preparation? It's Football!", Retrieved 10.9.2010, from http://asq.org/qm/2010/03/auditing/internal-auditpreparation-its-football-paper.html?shl=100490.

Risner, A. (2010), "Daimler-Chrysler Layered Process Audits (DCX LPA)", Retrieved 28.9.2010, from http://elsmar.com/pdf_files/Layered\%20Process\%20 Audit\%20Examples/Daimler-Chrysler\%20Layered\%20Process\%20Audits(2).ppt \#256,1,Daimler-Chrysler Layered Process Audits (DCX LPA).

Schmidt, U. (2007), “Daimler Process Audit Questionnaire”, MBC/QKF version 4.0 11/2007, Covisint, Germany.

Sdružení automobilového průmyslu VDA (1999), Audit procesu, Proces vzniku výrobku / sériová výroba, Proces vzniku služby / poskytováni služby, Česká společnost pro jakost, Česká republika.

\section{ABOUT THE AUTHOR}

Lubomír Lengyel is acting as a quality manager in company Faurecia Kosice, member of Faurecia group, which is an important supplier of automotive industry worldwide, e-mail: lubomir.lengyel@faurecia.com 